\title{
PENGARUH MODEL PEMBELAJARAN THINK PAIRED SHARE TERHADAP HASIL BELAJAR DAN KEMAMPUAN KOMUNIKASI SISWA SMKN 7 MEDAN
}

\author{
Muhammad Fitri Rahmadana ${ }^{\text {1)*, Isra Rafika }}{ }^{2)}$ \\ 1) Fakultas Ekonomi, Universitas Negeri Medan \\ 2) Alumni Fakultas Ekonomi, Universitas Negeri Medan \\ *Penulis korespondensi: mufitra@unimed.ac.id
}

\begin{abstract}
This study aims to analyze the application of Think Paired Share learning model to learning outcomes and communication skills of students in SMKN 7 Medan. Research that is a Pretest - Posttest Control Group experiment this design uses two classes as a sample, where one class is as an experimental class and another class as a control class. Data of learning outcome variable was taken using test, while data variable of communication skills was taken using questionnaire. While the data analysis techniques used t-test is not paired. The results showed that there were significant differences in learning outcomes and communication skills between experimental and control classes, where the learning outcomes and experimental class communication skills were higher than control classes, whereas previously homogeneity tests were conducted before the tests and questionnaires were given to the respondents. This shows that the Think Paired Share learning model is effective in improving students' learning outcomes and communication skills especially on economic subjects.
\end{abstract}

Keywords: Think Pair Share, Learning Outcomes, Communication Skill, t-test 


\section{PENDAHULUAN}

Dalam kegiatan belajar mengajar yang ada saat ini kemampuan untuk memahami dan mengungkapkan makna apa yang terdapat dalam pembelajaran sangat di butuhkan karena siswa dituntut untuk aktif dalam pembelajaran, kritis dan dapat berinteraksi dengan lingkungan sekitar. Dan harapannya akan mencapai hasil belajar yang memuaskan. Namun, pada kenyataannya banyak siswa yang memiliki hasil belajar yang rendah atau tidak lulus KKM, hal ini terlihat dari hasil belajar siswa yang ada pada tabel 1. Hasil belajar yang rendah diakibatkan oleh banyak siswa yang tidak memahami pelajaran yang dijelaskan guru dikelas, karena siswa cenderung diam dan pasif. Pada saat kesempatan bertanya diberikan kepada siswa, banyak siswa yang tidak menggunakan kesempatan yang diberikan, karena alasan malu terhadap temen - teman yang ada dikelasnya, dan juga malu kepada guru. Sikap yang pasif dalam belajar, dapat menjadikan siswa tersebut gagal dalam studinya.

Kemampuan dalam berkomunikasi juga belum dimiliki sepenuhnya oleh siswa SMK Negeri 7 Medan karena siswa merasa segan dan takut pada gurunya. Hal ini mengakibatkan kebosanan dalam diri siswa untuk belajar lebih baik. Siswa terbiasa dibimbing untuk mengikuti langkah dan prosedur yang ada dan mengerjakan serta menyelesaikan sesuatu sehingga mereka terbiasa mengikuti petunjuk yang ada dan tidak membutuhkan proses berpikir. Permasalahan ini dapat diminimalkan denga cara meningkatkan kemampuan komunikasi. Seseorang dapat berkomunikasi dengan mudah dengan orang lain jika memiliki kemampuan komunikasi yang baik, dan juga dengan komunikasi seseorang dapat mengekspresikan diri dan perasaannya, saling bertanya, menjawab dan saling berbagi dengan orang lain.

Tabel 1. Daftar Nilai Ujian Harian Komunikasi Bisnis Siswa Kelas XI PM

SMK Negeri 7 Medan
NIAGAWAN Vol 7 No 1 Maret 2018 (pembelajaran kooperatif) menghasilkan prestasi yang lebih tinggi, hubungan yang lebih positif dan penyesuaian psikologis yang lebih baik daripada suasana belajar yang penuh persaingan dan memisah-misahkan siswa". Pembelajaran kooperatif disusun sebagai sebuah usaha untuk meningkatkan partisipasi siswa, memfasilitasi siswa dengan pengalaman kepemimpinan dan membuat keputusan dalam kelompok, serta memberikan kesempatan kepada siswa untuk berinteraksi dan belajar bersama-sama siswa yang berbeda latar belakangnya. Jadi dalam pembelajaran kooperatif siswa berperan ganda, yaitu sebagai siswa ataupun sebagai guru. Dengan bekerja secara kolaboratif untuk mencapai sebuah tujuan bersama, maka siswa akan mengembangkan keterampilan berkomunikasinya.

Terdapat beberapa model pembelajaran kooperatif, salah satu model pembelajaran kooperatif yang memenuhi indikator kemampuan berkomunikasi siswa adalah model pembelajaran Think Pair Share (TPS) yang pertama kali dikembangkan oleh Frank Lyman dan koleganya di Universitas Maryland. Menurut Nurhadi (2004:23) menyatakan bahwa "Think Pair Share merupakan struktur pembelajaran yang dirancang untuk mempengaruhi pola interaksi siswa, agar tercipta suatu pembelajaran kooperatif yang dapat meningkatkan penguasaan akademik dan keterampilan siswa". Selain itu, TPS juga merupakan salah satu model pembelajaran yang dikembangkan dari teori konstruktivisme yang merupakan perpaduan antara belajar secara mandiri dan belajar secara berkelompok. Pendekatan konstruktivisme merupakan proses pembelajaran yang menerangkan bagaimana pengetahuan disusun dalam pemikiran pelajar.

Sehingga dapat dikatakan bahwa think pair share adalah pola diskusi kelas menuntut siswa untuk lebih aktif dalam berpikir dan merespon serta saling membantu. Sedangkat menurut Arends (dalam Aryani, 2016:6) : Model pembelajaran think pair share (saling bertukar

\begin{tabular}{|c|c|c|c|c|c|}
\hline Kelas & $\begin{array}{c}\text { Jumlah } \\
\text { Siswa }\end{array}$ & KKM & \multicolumn{2}{|c|}{$\begin{array}{c}\text { Jumlah Siswa Yang } \\
\text { Lulus KKM }(\%)\end{array}$} & Ji \\
\hline XI PM - 1 & 33 Siswa & 70 & 11 & $33 \%$ & 22 \\
\hline XI PM -2 & 35 Siswa & 70 & 14 & $40 \%$ & 21 \\
\hline XI PM - 3 & 32 Siswa & 70 & 16 & $50 \%$ & \\
\hline Jumlah & 100 Siswa & & 41 & $41 \%$ & 59 \\
\hline
\end{tabular}

Sumber : SMK Negeri 7 Medan

Johnson (Arini, 06 agustus 2009), menyatakan bahwa "suasana belajar cooperative learning
Jumlah Sisypikintan secara berpasangan) merupakan struktur Tidak Lulus KKM \% \% $)$ Pemjaran kooperatif yang efektif untuk meningkatkan partisifasi siswa dan daya pikir s\$\$\$a. Hal ini memungkinkan dapat terjadi karena prosedurnya telah disusun sedemikian sehingga dapat memberikan waktu yang lebih banyak kepada siswa untuk berpikir, serta merespon sebagai salah satu cara yang dapat membangkitkan bentuk partisipasi siwa. 
Pengetahuan dikembangkan secara aktif oleh siswa itu sendiri dan tidak diterima secara pasif dari orang disekitarnya. Hal ini bermakna bahwa pembelajaran merupakan hasil dari usaha siswa itu sendiri dan bukan hanya ditransfer dari guru kepada siswa. Hal tersebut berarti siswa tidak lagi berpegang pada konsep pengajaran dan pembelajaran yang lama, dimana guru hanya menuangkan atau mentransfer ilmu kepada siswa tanpa adanya usaha terlebih dahulu dari siswa itu sendiri. Model pembelajaran kooperatif tipe TPS membantu siswa menginterpretasikan ide mereka bersama dan memperbaiki pemahaman siswa terhadap suatu konsep. Dengan demikian, model pembelajaran TPS dapat membantu siswa dalam meningkatkan kemampuan berkomunikasi. Komunikasi sangat penting karena mata pelajaran komunikasi bisnis tidak hanya menjadi alat berfikir yang membantu siswa untuk mengembangkan ilmu, menyelesaikan masalah dan menarik kesimpulan tetapi juga sebagai alat untuk mengkomunikasikan pikiran, ide dan gagasan secara jelas, tepat dan singkat..

\section{TINJAUAN PUSTAKA}

\section{Model Pembelajaran Think Pair Share}

Think pair share (TPS) merupakan strategi pembelajaran yang dikembangkan pertama kali oleh Profesor Frank Lyman and koleganya di University of Maryland pada 1981 menyatakan bahwa think pair share merupakan suatu cara yang efektif untuk membuat variasi suasana pola diskusi kelas dan diadopsi oleh banyak penulis di bidang pembelajaran kooperatif pada tahun tahun selanjutnya. "Strategi ini memperkenalkan gagasan tentang waktu 'tunggu atau berpikir' (wait or think time) pada elemen interaksi pembelajaran kooperatif yang saat ini menjadi salah satu faktor ampuh dalam meningkatkan respon siswa terhadap pernyataan" (Huda, 2014:206).

"Strategi think pair share (TPS) atau berpikir berpasangan berbagi adalah merupakan jenis pembelajaran kooperatif yang dirancang untuk memengaruhi pola interaksi siswa" (Al-tabany 2014:129). Model pembelajaran TPS merupakan strategi diskusi untuk meningkatkan partisipasi siswa, model pembelajaran diskusi kelas mempunyai keuntungan dan kelemahan. Menurut Huda (2013:206) mengungkapkan terdapat beberapa manfaat TPS antara lain adalah :1) memungkinkan siswa untuk bekerja sendiri dan bekerja sama dengan orang lain; 2) mengoptimalkan partisipasi siswa; dan 3) memberi kesampatan kepada siswa untuk menunjukkan partisipasi mereka kepada orang lain. Skill - skill yang umumnya dibutuhkan dalam strategi ini adalah sharing informasi, bertanya, meringkas gagasan orang lain, dan paraphrasing.

Model pembelajaran TPS merupakan strategi diskusi untuk meningkatkan partisipasi siswa, model pembelajaran diskusi kelas mempunyai keuntungan dan kelemahan, menurut Suryosubroto (dalam Trianto 2012:134) terdapat beberapa keuntungan antara lain yaitu : 1) Melibatkan seluruh siswa dalam KBM., 2) Setiap siswa dapat menguji tingkat pengetahuan dan penguasaan bahan masing-masing, 3) Menumbuhkan dan mengembangkan cara berfikir dan bersikap ilmiah, 4) Interaksi siswa dapat memperoleh kepercayaan akan kemampuannya dirinya sendiri, 5) Dapat menunjang usaha sikap sosial dan demokratis siswa.

Shoimin (dalam Ginting 2015:9-10) menyatakan terdapat keterampilan sosial dalam proses pembelajaran think pair share antara lain :

1. Keterampilan sosial siswa dalam berkomunikasi meliputi dua aspek

a) Aspek bertanya.

Aspek bertanya meliputi keterampilan sosial siswa dalam hal bertanya kepada teman dalam satu kelompoknya ketika ada materi yang kurang dimengerti serta pada diskusi kelas.

b) Aspek menyampaikan ide atau pendapat.

Meliputi keterampilan siswa menyampaikan pendapat saat diskusi kelompok serta berpendapat saat kelompok lain persentasi.

2. Keterampilan sosial aspek bekerja sama. Keterampilan sosial siswa pada aspek yang bekerja sama meliputi keterampilan sosial siswa dalam hal bekerja sama dengan teman dalam satu kelompok untuk menyelesaikan soal yang diberikan oleh guru.

3. Keterampilan sosial aspek menjadi pendengar yang baik.

Keterampilan sosial siswa pada aspek menjadi pendengar yang baik, yaitu keterampilan dalam hal mendengarkan guru, teman dari kelompok lain saat sedang presentasi maupun saat teman dari kelompok lain perpendapat.

4. Komponen pembelajaran kooperatif tipe TPS.

Pembelajaran think pair share mempunyai beberapa komponen :

a) Think (berpikir)

b) Pair (berpasangan) 
c) Share (berbagi)

Dari paparan diatas penulis dapat menarik kesimpulan bahwa model pembelajaran kooperatif tipe think pair share merupakan model pembelajaran yang dapat mempengaruhi pola interaksi siswa. Keunggulan dari think pair share ini adalah optimalisasi partisifasi siswa. Dengan metode klasikal yang memungkinkan hanya satu siswa maju dan membagikan hasilnya untuk seluruh kelas, model think pair share ini memberikan kesempatan pada setiap siswa untuk menunjukkan partisipasi mereka kepada orang lain. Model ini bisa digunakan dalam semua mata pelajaran dan untuk semua tingkat anak didik.

\section{Kemampuan Berkomunikasi}

Kurniawati (2014:75-77) dalam bukunya menjelaskan terdapat 3 (tiga) model komunikasi antarpribadi yaitu :

1. Model Linear : Lasswell (1948) menggambarkan model pertama yaitu linear. Ini adalah model verbal yang terdiri dari lima pertanyaan yang menggambarkan urutan tindakan yang membentuk komunikasi (1) Siapa?, (2) Mengatakan apa?, (3) Dalam saluran apa?, (4) kepada siapa? (5) dengan efek apa?. Model linear memiliki dua kelemahan yang serius. Pertama, mereka menggambarkan komunikasi sebagai mengalir hanya satu arah, dari pengiriman ke penerima. Ini berarti bahwa pendengar hanya mendengarkan : mereka tidak pernah mengirim messages. Kedua, model linier menggambarkan pendengaran pasif menyerap pesan pengirim tapi tidak memiliki dampak apapun pada pengirim. Tapi ini bukan bagaimana komunikasi benar - benar terjadi.

2. Interaktif Model : Menurut Weiner (1967) fitur utama dari model interaktif adalah umpan balik, yang merupakan tanggapan terhadap pesan. Umpan balik dapat berbentuk lisan, nonverbal, atau keduanya, dan mungkin disengaja atau tidak disengaja.

3. Model Transaksi : Model transaksional menggambarkan masing - masing bidang pribadi pengalaman dan bidang berbagai pengalaman antara komunikator sebagai perubahan dari waktu ke waktu. Seperi kita mengadapi orang - orang baru dan memiliki pengalaman baru yang memperluas kita secara pribadi, kita
NIAGAWAN Vol 7 No 1 Maret 2018 mengubah cara kita berinteraksi dengan orang lain.

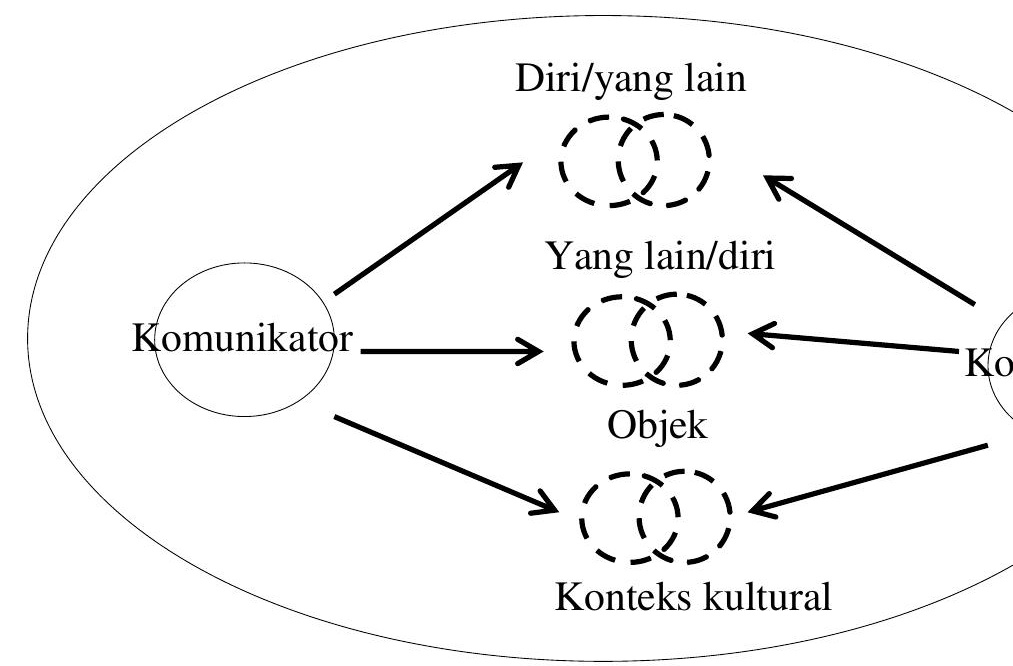

Gambar 1. Skema Model transaksional

Demi memperbaiki komunikasi interpersonal atau untuk efektivitas antarpribadi dapat dilihat dari tiga sudut pandang, yaitu antara lain :

a) Sudut pandang humanistik dimulai dengan kualitas umum yang menurut para filsuf dan humanis menentukan hubungan antara manusia yang superior. Model humanistik untuk efektivitas antarpribadi menekankan pada lima kualitas : (1) Keterbukaan, (2) Empati, (3) Dukungan, (4) sikap positif, (5) kesetaraan.

b) Sudut pandang pragmatis, dipusatkan ada perilaku yang harus dugunakan oleh komunikator untuk mendapatkan hasil yang dikhendaki. Model pragmatis ini menekankan pada lima kualitas : (1) Rasa percaya diri, (2) Kebersatuan, (3) Manajemen interaksi, (4) Daya ekspresi, (5) Orientasi kepada pihak lain.

Sudut pandang pergaulan dan kesetaraan, dipusatkan pada pertukaran manfaat dan biaya, serta implikasi dari pola pertukaran ini terhadap hubungan. Model pragmatis ini dilkatiskan pada teori ekuitas (kesetaraan) yang menekankan pada empat kualitas : (1) Bertukar manfaat, (2) Menanggung beban biaya bagian, (3) mengintensifkan pertukaran manfaat pada saat biaya meningkat, (4) Memperbesar manfaat untuk mengurangi daya tarik alternative..

\section{METODE PENELITIAN}

Penelitian ini dilaksanakan di SMK Negeri 7 Medan mengambil Sampel 2 kelas yang diambil secara purposive sampling, yaitu kelas XI PM - 1 berjumlah 33 siswa sebagai 
kelas control dan kelas XI PM - 2 berjumlah 35 siswa sebagai kelas eksperimen. Penelitian ini termasuk quasi eksperimen yang bertujuan untuk melihat atau mengetahui ada tidaknya akibat dari sesuatu yang dikenakan pada subjek yaitu siswa. Dengan memberikan perlakuan pada kelompok sampel penelitian melalui model pembelajaran think pair shere. Rancangan penelitian ini menggunakan model two-group-pretest-posttest design (Sudjana, 2005). Di dalam design ini, sebelum dimulai perlakuan, kedua kelompok diberikan test awal ataupun pre-test untuk mengukur kondisi awal. Selanjutnya diberikan perlakuan. Sesudah selesai perlakuan, kedua kelompok diberikan test sebagai post-test. Rancangan ini dapat di gambarkan sebagai berikut:

Tabel 2. Pretest-posttest Control Group Desain

\begin{tabular}{|c|c|c|c|}
\hline Kelas & $\begin{array}{c}\text { Pre }- \\
\text { test }\end{array}$ & Perlakuan & $\begin{array}{c}\text { Post - } \\
\text { test }\end{array}$ \\
\hline $\begin{array}{c}\text { Eksperimen (XI } \\
\text { PM - 2) }\end{array}$ & $\mathrm{T}_{1}$ & $\mathrm{X}_{1}$ & $\mathrm{~T}_{2}$ \\
\hline $\begin{array}{c}\text { Kontrol (XI PM - } \\
1 \text { ) }\end{array}$ & $\mathrm{Q}_{1}$ & $\mathrm{X}_{2}$ & $\mathrm{Q}_{2}$ \\
\hline
\end{tabular}

Keterangan :

$\mathrm{T}_{1 \text { : }}$ Test awal dan penyebaran angket pada kelas eksperimen

$\mathrm{Q}_{2}$ : Test awal dan penyebaran angket pada kelas kontrol

$\mathrm{X}_{1:}$ Perlakuan dengan menggunakan model pembelajaran think pair share

$\mathrm{X}_{2}$ : Perlakuan dengan menggunakan pembelajaran konvensional

$\mathrm{T}_{2}$ : Test dan penyebaran angket setelah pemberian perlakuan mengajar pada kelas eksperimen

$\mathrm{Q}_{2}$ : Test dan penyebaran angket setelah pemberian perlakuan mengajar pada kelas control

Instrument yang digunakan dalam penelitian ini adalah tes hasil belajar siswa berupa tes bentuk pilihan ganda sebanyak 20 soal. Tes digunakan untuk mengukur penguasaan siswa terhadap materi yang diberikan dan melihat ketuntasan belajar. Setiap soal memiliki 5 option (a,b,c,d dan e) dan jawaban yang benar diberi skor 5 sedangkan jawaban yang salah diberi skor 0 . Pengambilan data dilakukan diawal (pre test) dan di akhir pembelajaran (post test).

Variabel berkomunikasi memiliki 4 alternatif jawaban, yaitu : $\mathrm{SS}=$ sangat sering, $\mathrm{S}=$ sering, $\mathrm{J}$ $=$ jarang, $\mathrm{SJ}=$ sangat jarang
Tabel 3. Lay Out Angket

\begin{tabular}{|l|l|l|l|l|}
\hline \multirow{2}{*}{ No } & \multirow{2}{*}{$\begin{array}{c}\text { Aspek yang } \\
\text { dipertanyakan }\end{array}$} & \multirow{2}{*}{ Indikator } & \multicolumn{2}{|c|}{ No Item } \\
\cline { 4 - 5 } & & & \multicolumn{1}{|c|}{+} & \multicolumn{1}{|c|}{-} \\
\hline 1. & Kemampuan & 1. Keterbukaan & $1,2,4,20$ & 3,22 \\
& berkomunikasi & 2. Empati & $5,6,7$ & $8,23,24$ \\
& & 3. Dukungan & $10,11,12,25$ & 9,26 \\
& & 4. Rasa positif & $13,16,27,28$ & 13,14 \\
& & 5. Kesamaan & $17,18,2,29,30$ & 19,20 \\
& & & & \\
\hline
\end{tabular}

Sumber : Model humanistik (dalam kurniawati, 2014:77)

Data yang diolah adalah data hasil belajar siswa dan angket kemampuan berkomunikasi pada kelas Eksperimen (pengajaran dengan model pembelajaran think pair share) dan kelas control (pengajaran dengan menggunakan model pembelajaran Konvensional). Uji hipotesis dilakukan dengan uji t tidak berpasangan dengan membandingkan $t_{\text {hitung }}$ dengan $t_{\text {tabel }}$ dengan rumus sebagai berikut :

$$
t=\frac{\bar{x}_{1}-\bar{x}_{2}}{\sqrt{\frac{\left(n_{1}-1\right) s_{1}^{2}+\left(n_{2}-1\right) s_{2}^{2}}{n_{1}+n_{2}-2}\left(\frac{1}{n_{1}}+\frac{1}{n_{2}}\right)}}
$$

Sugiono (2012:273)

Keterangan :

$\overline{\mathrm{X}_{1}}=$ rata - rata nilai kelas eksperimen

$\overline{\mathrm{X}_{2}}=$ rata - rata nilai kelas kontrol

$\mathrm{n}_{1}=$ jumlah siswa pada kelas eksperimen

$\mathrm{n}_{2}=$ jumlah siswa pada kelas kontrol

$\mathrm{S}_{1}^{2}=$ varian pada kelas eksperimen

$\mathrm{S}_{2}^{2}=$ varian pada kelas control

\section{HASIL DAN PEMBAHASAN}

\section{Uji Instrumen Penelitian}

Sebelum instrument penelitian diujikan maka terlebih dahulu melakukan uji coba instrument. Hal ini dilakukan bertujuan untuk mengetahui validitas dan reabilitas pre test/post test dan angket penelitian. Uji validitas instrument dilakukan dengan menggunakan metode korelasi product moment dan uji reliabilitas dilakukan dengan menggunakan Cronbach Alpha yang perhitungannya dibantu dengan SPSS 18.0 untuk pre test/post test dan angket penelitian serta uji daya pembeda dan uji tingkat kesukaran soal soal untuk pre test/post test.

Uji Validitas Kemampuan Komunikasi terhadap 25 butir angket menunjukkan bahwa hanya 21 butir soal saja yang valid atau yang telah memenuhi kriteria dimana nilai signifikansi $<0.05$. Sedangkan Uji validitas dari 
30 butir soal yang disediakan menunjukkan bahwa hanya 22 butir pernyataan saja yang valid untuk diujikan kepada para siswa.

Uji reliabilitas angket menunjukkan bahwa nilai croanbach alpha sebesar 0,742. Nilai tersebut lebih besar dari r-tabel pada tarif signifikan $95 \%$ dengan alpha $5 \%$ yaitu 0,367 . Angka ini menunjukkan bahwa butir soal ini terbukti reliable untuk digunakan karena $r$ hitung $>\mathrm{r}$ tabel $(0,742>0,361)$. Uji reliabilitas tes diperoleh croanbach alpha sebesar 0,946. Nilai tersebut lebih besar dari r-tabel pada taraf signifikan 95\% dengan alpha $5 \%$ yaitu 0,367. Angka ini menunjukkan bahwa angket ini terbukti reliable untuk digunakan karena $r$ hitung > r tabel $(0,946>0,367)$.

Secara khusus untuk soal test dilakukan uji Daya Pembeda soal. Hasil uji daya pembeda soal menunjukkan bahwa 21 butir soal yang disediakan dapat dianalisa daya pembeda diperoleh 3 butir dalam keadaan sangat baik, 16 butir dalam keadaan baik, 1 butir dalam keadaan cukup, dan 1 butir dalam keadaan kurang/jelek.

Selanjutnya dilakukan uji Indeks Kesukaran Soal yang menunjukkan bahwa 21 butir soal yang disediakan 1 butir soal termasuk ke dalam kategori sukar , 17 butir soal masuk dalam kategori sedang, dan 3 butir soal termasuk ke dalam kategori mudah.

\section{Uji Hipotesis}

Uji hipotesis dilakukan untuk melihat ada tidaknya perbedaan yang signifikan pada taraf tertentu dari variabel yang diteliti. Pengujian hipotesis menggunakan rumus uji-t tidak berpasangan. Untuk perhitungan uji hipotesis menggunakan uji-t pada tingkat kepercayaan $95 \%$ pada $a=0,05$. Uji ini digunakan untuk mengetahui apakah hipotesis dalam penelitian ini diterima atau ditolak. Kriteria pengujian jika $T_{\text {hitung }}>T_{\text {tabel }}$ maka hipotesis alternative (Ha) diterima dan jika sebaliknya maka hipotesis nol (Ho) ditolak.

Tabel 4

Hasil uji hipotesis Dengan Menggunakan

Bantuan SPSS

\begin{tabular}{|c|c|c|c|c|}
\hline Sumber data & kelas & $\begin{array}{l}\mathrm{T} \\
\text { hitung }\end{array}$ & $\mathrm{T}_{\text {tabel }}$ & keterangan \\
\hline \multirow[t]{2}{*}{ Hasil belajar } & eksperimen & \multirow[t]{2}{*}{2.067} & \multirow{4}{*}{1.671} & \multirow{2}{*}{$\begin{array}{l}\text { Hipotesis } \\
\text { diterima }\end{array}$} \\
\hline & kontrol & & & \\
\hline \multirow{2}{*}{$\begin{array}{l}\text { Kemampuan } \\
\text { komunikasi }\end{array}$} & eksperimen & \multirow[t]{2}{*}{3.180} & & \multirow{2}{*}{$\begin{array}{l}\text { Hipotesis } \\
\text { diterima }\end{array}$} \\
\hline & kontrol & & & \\
\hline
\end{tabular}

Berdasarkan hasil pengujian hipotesis pengingkatan hasil belajar siswa diperoleh harga
NIAGAWAN Vol 7 No 1 Maret 2018 $\mathrm{T}_{\text {hitung }}>\mathrm{T}_{\text {tabel }}$ yakni $2.067>1.671$ untuk hasil belajar komunikasi bisnis dan harga $\mathrm{T}_{\text {hitung }}>$ $\mathrm{T}_{\text {tabel }}$ yakni $3.180>1.671$ untuk kemampuan komunikasi dengan taraf signifikan $(a=0,05)$ sehingga Ha1 dan Ha2 diterima dan Ho1 dan Ho2 ditolak maka dapat disimpulkan model pembelajaran dapat meningkatkan hasil pelajar komunikasi bisnis dan kemampuan komunikasi siswa.

\section{Pembahasan Hasil Penelitian}

Penelitian yang dilaksanakan di SMK Negeri 7 Medan melibatkan dua kelas dengan memberikan perlakukan pembelajaran yang berbeda pada kedua kelas. Kelas XI- PM 1 sebagai kelas eksperimen diberi perlakuan berupa pembelajaran dengan mengunakan model Think Pair Share dan kelas XI- PM 2 sebagai kelas kontrol diberi perlakuan berupa pembelajaran dengan menggunakan model Konvensional.

Setelah instrument penelitian selesai diuji validitas, reliabilitas, tingkat kesukaran dan daya pembedanya. Maka peneliti melanjutkan proses penelitian, proses penelitian dilakukan didalam kelas. Sebelum pembelajaran dimulai, terlebih dahulu diadakan pre test kepada kedua kelas yang bertujuan untuk melihat kemampuan awal siswa dalam materi Teknik Presentasi. Dari hasi pre test yang dilakukan, dilakukan hitung uji normalitas dan uji homogenitas.. Dapat disimpulkan bahwa data kelas eksperimen dan kelas kontrol normal dan tidak ada perbedaan yang signifikan antara kemampuan awal siswa kelas eksperimen dan kelas Kontrol. Hal ini berarti sampel memenuhi kreteria untuk diberikan perlakuan, dengan kata lain penelitian bisa dilanjutkan dengan sampel tersebut.

Proses pembelajaran dengan materi teknik presentasi dimana kelas eksperimen terjadi 2 kali pertemuan dan kelas kontrol 2 kali pertemuan yang mana peneliti sendiri yang membawakannya pada kelas kontrol dan kelas eksperimen. Pada akhir pertemuan peneliti memberikan post test dan angket kemampuan komunikasi guna melihat hasil belajar yang diperoleh dari proses pembelajaran yang telah berlangsung. Dari data pre test dan post test yang letah diberoleh hasil, dan inilah yang digunakan peneliti untuk proses pengelolaan data guna keperluan peneliti, dan di uji kembali. Berdasarkan hasil perhitungan untuk pengujian hipotesis dari hasil post test yang dilakukan diperoleh $\mathrm{T}_{\text {hitung }}=2.064$ Dan $\mathrm{T}_{\text {tabel }}=1.671 \mathrm{dan}$ kemampuan komunikasi diperoleh $\mathrm{T}_{\text {hitung }}=3.180$ 
Dan $\mathrm{T}_{\text {tabel }}=1.671$ pada tingkat kepercayaan $95 \%$ dan taraf nyata $\mathrm{a}=0,05$ dengan $\mathrm{dk}=\mathrm{n} 1+\mathrm{n} 2$ $2=33+35-2=66$ diperoleh $t_{(0,95)(66)}$ sebesar 1.671 dengan cara interpolasi linier. Dengan membandingkan kedua nilai tersebut maka dapat disimpulkan Thitung $>\mathrm{T}_{\text {tabel }}$ yaitu $2.064>1.671$ untuk hasil belajar komunikasi bisnis dan harga $\mathrm{T}_{\text {hitung }}>\mathrm{T}_{\text {tabel }}$ yakni $3.180>1.671$ untuk kemampuan komunikasi Hal ini berarti hipotesis nol (Ho) ditolak dan hipotesis alternative penelitian (Ha) diterima yang menyatakan bahwa hasil belajar komunikasi bisnis yang diajarkan dan kemampuan komunikasi siswa dengan model pembelajaran Think pair share yang diterapkan lebih tinggi daripada hasil belajat komunikasi bisnis yang diajarkan dan kemampuan komunikasi dengan menggunakan metode konvensional.

Siswa dikelas eksperimen dengan model pembelajaran think pair share lebih antusias/aktif dan fokus dalam kegiatan pembelajaran dibandingkan dengan siswa yang ada dikelas kontrol. Hal ini berdampak pada pemahaman siswa kelas eksperimen pada materi yang diajarkan lebih baik dan optimal dibantingkan siswa dikelas kontrol. Dengan demikian maka hipotesis yang menyatakan hasil belajar komunikasi bisnis dan kemampuan komunikasi siswa yang diajarkan dengan model pembelajaran think pair share diterapkan lebih tinggi signifikan daripada hasil belajar komunikasi bisnis dan kemampuan komunikasi siswa yang diajarkan dengan metode konvensional siswa SMK Negeri 7 Medan T.P 2016/2017 dapat diterima.

\section{KESIMPULAN DAN SARAN}

Berdasarkan hasil penelitian dan pembahasan maka disimpulkan bahwa hasil belajar komunikasi bisnis dan kemampuan komunikasi siswa pada materi presentasi yang diajarkan menggunakan model pembelajaran think pair share lebih tinggi secara signifikan daripada hasil belajar komunikasi bisnis dan kemampuan komunikasi siswa yang diajarkan dengan metode konvensional. Oleh sebab itu maka guru bidang studi komunikasi bisnis hendaknya mampu meningkatkan keterampilan mengajar dengan terus melakukan inovasi dalam proses pembelajaran dikelas dengan model pembelajaran think pair share agar hasil belajar lebih maksimal. Pihak sekolah juga diharapkan lebih memperhatikan dan mendorong para guru untuk selalu menggunakan model pembelajaran yang beragam dan sesuai untuk meningkatkan hasil belajar siswa. Kedepannya diharapkan kajian-kajian tentang model-model pembelajaran khususnya di bidang ekonomi dapat dilakukan untuk materi yang berbeda.

\section{REFERENSI}

Al-Tabany, Trianto Ibnu Badar. 2014. Mendesain Model Pembelajaran Inovatif, Progresif, dan Kontekstual. Surabaya:Kencana.

Arini, Yusti. 2009. Pembelajaran kooperatif.Yusti-

arini.blogspot.co.id/2009/08/modelpembelajaran-kooperatif.html $? m=1 \quad(01$ Maret 2017).

Arikunto, Suharsimi. 2013. Dasar - Dasar Evaluasi Pendidikan. Jakarta : PT. Bumi Aksara.

2014. Prosedur

Penelitian. Jakarta : PT. Bumi Aksara

Aryani, Ade Tri. 2016. Penerapan Model Pembelajaran Kooperatif Think Pair Share Untuk Meningkatkan Kemampuan Komunikasi Matematika Siswa Pada Materi Faktorisasi Aljabar Di SMP N 1 Teluk Mengkudun T.A 2015/2016.Skripsi. Medan : UNIMED.

Depdiknas. 2006. Undang - Undang RI No 20 Tahun 2003 tentang Sistem Pendidikan Nasional. Bandung : Permata.

Ginting, Henna Wahyuni. Pengaruh Model Pembelajaran Think Pair Share Terhadap Hasil Belajar Ekonomi Kelas IX IPS SMA Negeri 1 Kutalimbaru Deli Serdang T.A 2015/2016. Skripsi. Medan : UNIMED.

Harahap, Tua Halomoan. 2013. Penerapan Contextual Teaching And Learning (Ctl) Untuk Meningkatkan Kemampuan Koneksi Dan Representasi Matematika Siswa Kelas Vii-2 SMP Nurhasanah Medan Tahun Ajaran 2012/2013. Skripsi. Medan : UNIMED.

Huda, Miftahul.2013. Model - Model Pengajaran dan Pembelajaran. Yogyakarta : Pustaka Pelajaran.

Husna dkk. (April 2013). Peningkatan Kemampuan Pemecahan Masalah Dan Komunikasi Matematis Siwa Sekolah Menengah Pertama Melalui Model Pembelajaran Kooperatif Tipe ThinkPair-Share. Jurnal Peluang (PTS) 2013 : $2: 2302-5158$. 
Kurniawati, Rd Nia Kania.2014. Komunikasi

Antarpribadi Konsep dan

Teori.Yogyakarta : Graha Ilmu.

Madhirin. 2008. Metode Pembelajaran Efektif. http://nadhirin.blogspot.co.id/2008/08/m etode-pembelajaran-efektif.html $\quad(01$ Maret 2017).

Nababan, Renita. 2011. Penerapan Model Pembelajaran Kooperatif Tipe Think Pair Share (TPS) Untuk Meningkatkan Hasil Belajar Ekonomi Siswa Kelas XI SMA Negeri 1 Parbuluan T.A 2010/2011. Skripsi. Medan : UNIMED.

Naizhela, Mosik (Januari 2015). Peningkatan Hasil Belajar Melalui Pendekatan Kontekstual Dengan Metode Think-PairShare. Unnes physics education journal $2015: 4: 2252-6935$.

Novi R.S. 2016.Penerapan Pembelajaran Think - Pair - Share Berbasis Budaya Batak Toba Untuk Meningkatkan Kemampuan Komunikasi Dan Berpikir Krisis Matematika Siswa Kelas IX SMP ETIS LANDIA MEDAN T.A 2016/2017. Skripsi. Medan : UNIMED.

Risanti. 2013. Penerapan Model Pembelajaran Kooperatif Tipe Think Pair Share (TPS) Terhadap Hasil Belajar Kewirausahaan Siswa SMK Laksamana Martadinata Medan Tahun Ajaran 2012/2013. Skripsi. Medan : UNIMED.

Sudjana, 2012. Metoda Statistika. Bandung: Tarsito.

Sugiyono, 2008. Metode Penelitian Kuantitatif,

Kualitatif dan R\&D. Bandung:

Alfabeta.

Syihab, Amir nur. 2013. Penerapan Model Pembelajaran Think-Pair-Share Melalui Public Speaking Untuk Meningkatkan Keterampilan Komunikasi Siswa (Pada Mapel Kompetensi Kejuruan Kompetensi Dasar Mc Kelas X1 Ap 1 Jurusan Administrasi Perkantoran Smk N 2 Blora Tahun Ajaran 2012/2013). Skripsi. Semarang: UNNES.

Trianto. 2009. Mendesain Model Pembelajaran Inivatif Progresif. Jakarta : Kencana. 2012. Penelitian Tindakan Kelas Teori

dan Praktek. Jakarta : Prestasi Pustakarya. 